\title{
Introduction: ideological nexus of the law convergence thesis
}

This introductory section aims to familiarise the reader with the ideological fundamentals of the legal harmonisation thesis and provide certain initial background information with regard to the strategic models and factors proposed in pursuit of the harmonisation of laws.

It is customary for academics to immerse themselves in their own subject and expertise to the point that the whole world around them may look perfectly irrelevant. Aware of this, the author would still opine that the harmonisation of legal systems thesis stands out as the leading thesis in the modern discipline of law.

The reader is, therefore, asked to bear in mind that the idea of harmonisation of legal systems holds a certain unique place in our discipline, the discipline of law. This is the thesis which came to define the new world order, as this arose from the ashes of torn nations after the end of the latest great war. Close to this, one must always recall that the legal harmonisation thesis in the post-Second World War world has been perfected on the tears of the fallen, the blood of the dead and the hopes of the living. Winston Churchill, Robert Schuman, Altiero Spinelli, Konrad Adenauer, Paul-Henri Spaak and Jean Monnet were certain of the political figures who saw magnificent benefit in the thesis, even though, at the time, these political giants saw the harmonisation of systems more as a political ideal rather than a legal ideal per se.

At the congruence of law, economics and political science, the legal harmonisation thesis talks about something very simple: the coming together of legal systems. Yet, this is not just another empty theoretical academic exercise for its own sake. Rather, one is alerted to the fact that the circles of legal convergence are created by willing participants. The armada of legal harmonisation projects thus proceeds through the able and the willing. The legal scholar must, thus, accept and acknowledge the fact that the legal ideal behind the harmonisation of legal systems is the offspring of political interference, in the first instance, and technocratic interference, in the second instance.

Nowadays, the law harmonisation scholar must otherwise navigate through political populisms and nationalisms, on the one hand, and 
dysfunctional and fallen bureaucracies, on the other hand. The ideal of the legal harmonisation thesis must be salvaged at all costs, whereas populist politics and remote bureaucracies ought to be disregarded in the path of such a thesis, a thesis which ought to promote the well-being of individuals, States and corporate actors alike. Complex as it is, the law harmonisation thesis could otherwise be perceived as the legal discipline's most perfect gift to humanity. This is a thesis which gives recognition to the nation-state but it equally posits that national considerations subside when wider legal considerations proceed beyond the local, the domestic and the national (always with the agreement of the domestic sphere).

It is cognition that provides one's trust in the harmonisation thesis, not belief. One's thesis in favour of the harmonisation of legal systems is not based on empty rhetoric or wishful idealism but on practical utility. As these lines are written, the world seems to be reverting, for a while, to nationalist and populist paths. Of course, such a phenomenon cannot halt the harmonisation initiatives which have already been agreed and tested in theory and in practice, as well as future harmonisation projects to be. However, the slowing down of such initiatives may be something which one may observe temporarily.

The realm of law otherwise sets the tone for the formal harmonisation of trade, human rights and laws which indeed transcend nation-states and systems. A harmonised norm is a superior form of norm. The vehicle for the harmonisation of systems is the nation-state. Equally, from the moment a state agrees to a harmonised norm it also normally agrees to the supremacy of such a form of norm to domestic law.

Beyond this, it is phobias and attitudes that keep peoples and nations apart from one another. The harmonisation thesis opposes such a state of affairs, for this is a thesis which opposes legal frontiers and barriers. In this respect, a world of perfect freedom in law is contemplated. Freedom is a fundamental ingredient of the harmonisation thesis. A world of free trade, genuinely recognising human rights and open socio-political systems are matters which operate at the heart of the modern harmonisation thesis. Let us not confuse such an environment of legal freedom, however, with abuse of the law; let us ensure that we do not surrender the harmonisation thesis to short-sighted political calculations; indeed, let us resist the temptation to identify the legal harmonisation thesis with the interests of technocratic elites and bureaucracies.

In any case, the legal harmonisation thesis must be about utility. Ultimately, legal harmonisation is about benefit and utility. As will be seen below, such benefit may or may not have to do with economic benefit (depending on the area of law) but, ultimately, the legal harmonisation 
thesis is about utility, practicality and benefit (whether political, economic or legal per se).

\section{IDEOLOGICAL CO-ORDINATES OF THE LEGAL HARMONISATION THESIS}

The law convergence thesis (which can be used as a synonym for the harmonisation of legal systems thesis) is characterised by a number of ideological features. Such features can be roughly divided into epistemic ideological features and ideological features per se. Thus, in relation to the epistemic ideology of the modern harmonisation thesis in law the following disciplines are of direct relevance: political science, law and economics. Furthermore, the phenomenon of harmonisation of systems is multifaceted; it expects:

- convergence of interests ${ }^{1}$ (political test);

- convergence of principle (legal test);

- comparison of efficiencies ${ }^{2}$ (economic test);

- materialisation of benefit (whether economic, legal, political or ideological).

The above come with a degree of conditionality; for instance, one would opine that the deferment of jurisdiction to the extra-national materialises on an implicit conditional basis. ${ }^{3}$

More narrowly, the precise philosophical ideological fundamentals of the law harmonisation thesis are found in Plato's one-over-many principle. Plato was the philosopher who first coherently and systematically examined the idea of the one in epistemic terms. As a philosopher,

1 'This [the project of legal unification] is political in nature, and must therefore be approached in a spirit of refinement and conciliation': R. David, 'The Methods of Unification' (1968) 16 American Journal of Comparative Law 26 and 'When national interests of different countries converged at a certain point of negotiation, integration was accelerated': N. Kim (ed.), 'Europe and East Asia: Holistic Convergence or Fundamental Skepticism?' in N. Kim, Globalization and Regional Integration in Europe and Asia (Farnham, Ashgate, 2009), p. 86.

2 R. Cotterrell, Law, Culture and Society (Farnham, Ashgate, 2006), pp. 147-8: 'regulatory efficiency ... no doubt gives comparatists a powerful impetus to work towards uniform law'.

3 C.F. Sabel and O. Gerstenberg, 'Constitutionalising an Overlapping Consensus: The ECJ and the Emergence of a Coordinate Constitutional Order' (2010) 16 European Law Journal 511, 550. 
he has, of course, offered us some of the most moving metaphors on our path to perceiving knowledge through reason. Fundamentally, it was in the Republic that the one-over-many thesis was crystallised. ${ }^{4}$ But in one of his other works, Phaedo, he put the idea of one-over-many into operation when discussing aesthetics. The elegance of his thought has been manifested in the example of beauty and what it stands for according to him:

if there is anything beautiful besides Beauty itself, it is beautiful for no other reason than that it shares in that Beauty ... nothing else makes it beautiful other than the presence of, or the sharing in, or however you may describe its relationship to that Beauty we mentioned, for I will not insist on the precise nature of the relationship, but that all things are made beautiful by Beauty. ${ }^{5}$

By extension, the ideology of harmonisation of laws must be one which analogically expects the participation, the sharing and the presence of a system in a circle of harmonisation. Recognition is, of course, made of the fact that systems are, presumably, whether by historical configuration, choice or accident, diverse. In conjunction with this diversity, just like in Plato's example of aesthetics analysis, the unity of and as between the participant systems of law ought to prevail and could prevail. One should add here that such unity is best achieved through means of democratic deliberation and participation. Finally, for clarity, unity through harmonisation does not exclude diversity from legal system to legal system and diversity, on occasion, may be very welcome indeed, especially in culturally defined and confined areas of law.

This brings us to the next point: the modern harmonisation thesis cannot but be characterised by democratic legitimacy. The harmonisation thesis through relevant norms may not always aim to and in itself democratise the domestic (even though it has, for example, through the European Convention on Human Rights judgments in Europe) but it would otherwise expect the circle of harmonisation to be based on democratic principle. Thus, a plurality of demoi is contemplated in our thesis. A universe of human actors is presupposed. In such a universe, the preferences of human beings come to prevail in determining the shape, the ethos, the structures and the features of democracy's laws. The whole of humanity is divided into such demoi (as opposed to being united in a single world demos). That is, humanity is necessarily divided into demoi (as there cannot be democracy in the absence of demos/demoi) and that division is a

4 Plato, Republic 596a: 'We are in the habit of positing a single Form for each plurality of things to which we give the same name'.

5 Plato, Phaedo $100 \mathrm{c}-\mathrm{d}$. 
force (though not an insuperable force) against rather than in support of convergence of laws. ${ }^{6}$

Finally, the harmonisation thesis must equate to anything but a static state of affairs. ${ }^{7}$ Our world is in perfect flux and old certainties vanish away in the face of new developments in almost all fields of life. What was a certainty yesterday is but a possibility today. Equally, probabilities of the past may manifest themselves into perfect certainties in the future. Law strives to meet the expectations of a humanity which operates in different ways to the ways in which it would operate only a few decades ago. It is, therefore, hoped that the harmonisation thesis will continue to evolve, as humanity does. In this respect, this monograph attempts to make a moderate contribution to the discussion relating to the future of the legal harmonisation thesis.

6 Acknowledgement is made to the contribution of Prof. Richard Kay of the University of Connecticut in respect of the position of the paragraph to which this footnote relates.

7 See e.g. on an indicative basis the relevant academic discourses in the wider field of legal harmonisation studies by such authors as Twining, Andersen, Slaughter and the author of this monograph in recent years: W. Twining, 'Diffusion of Law: A Global Perspective' (2004) 49 Journal of Legal Pluralism 1; C. Baasch Andersen, 'Defining Uniformity in Law' (2007) 12 Uniform Law Review 5; C. Baasch Andersen, 'The Global Jurisconsultorium of the CISG Revisited' (2005) 24 Journal of Law and Commerce 159; A.-M. Slaughter, 'Sovereignty and Power in a Networked World Order' (2004) 40 Stanford Journal of International Law 283 and A.E. Platsas, 'The Idea of Legal Convergence and International Economic Law' (2009) 2 International Journal of Private Law 385. 